\title{
A Comparison of Models for Predicting Discretionary Accruals: A Cross-Country Analysis
}

\author{
Goksel ACAR ${ }^{1}$, Ali COSKUN ${ }^{2}$
}

Received: June 22, 2020 Revised: July 12, 2020 Accepted: August 10, 2020

\begin{abstract}
In this study, we examined various aspects of discretionary accruals. We compared the power of Jones Model (JM), Modified Jones Model (MJM) and Performance Matched Model (PMM). Furthermore, we tested whether accruals derived from cash flow approach or balance sheet approach provide better results and we investigated the significance of country and industry control variables in models. In order to perform these tests, we constructed thirty equations. The data consists of 319 non-financial companies over five years in the GCC region. We used panel data regression models, and testing suggests us to use random effect model as the most suitable one. The results show that PMM has the highest explanatory power among models and it is followed by JM and MJM, consecutively. Secondly, results reveal that accruals derived from cash flow approach provide more accurate results. Moreover, country dummies are significant in models with cash flow approach and they lose significance in balance sheet approach. We differentiated industries due to two different classifications: the first group with higher number of industries is more precise compared to the second group with a narrower scope and lower number of industries. The model including both industrial and country-wise dummies scores highest in significance.
\end{abstract}

Keywords: Discretionary Accruals, Earning Management, Financial Reporting, GCC, Industry Differences

JEL Classification Code: C18, C51, M41

\section{Introduction}

The accounting manipulation topic has been attracting scholars and practitioners for many decades. Earnings management, as a type of manipulation, accounts for a considerable share in this literature. Schipper (1989) defines earnings management as the "purposeful intervention in the external financial reporting process, with the intent of obtaining some private gain." Earnings management aims to mislead users of financial information in a way that manipulators gain some advantage, such as an increase in

${ }^{1}$ First Author. Department of Finance and Economics, College of Commerce and Business Administration, Dhofar University, Oman. Email: gacar@du.edu.om

${ }^{2}$ Corresponding Author. Department of Accounting, College of Business Administration, American University of the Middle East, Kuwait [Postal Address: Egaila Block 6, Ahmedi, 54200, Kuwait] Email: ali.coskun@aum.edu.kw

() Copyright: The Author(s)

This is an Open Access article distributed under the terms of the Creative Commons Attribution Non-Commercial License (https://creativecommons.org/licenses/by-nc/4.0/) which permits unrestricted non-commercial use, distribution, and reproduction in any medium, provided the original work is properly cited. share prices, avoiding taxes and some other regulations, getting advantage for debt covenants, etc.

Mulford and Comiskey (2002) have summarized the motives behind manipulation in four groups: share price effects, borrowing cost effects, bonus plan effects, and political cost effects. Two groups are focusing on the investigation of earnings management show differences. Practitioners, such as auditors and tax officers, focus on individual cases. They have a higher chance to collect data for their research. Yet, scholars do not have such opportunities, and their aim also differs in a way that they do not merely focus on individual cases; instead, they try to induce a generalized result for their research (Dechow \& Skinner, 2000). In order to give a general insight into their research, scholars have developed many models to deduct earnings management.

Though it is one of the prominent areas in accounting and finance literature, earnings management studies bear considerable contradiction in predicting accruals. Widely used models, such as Jones Model (Jones, 1991), Modified Jones Model (Dechow, Sloan, \& Sweeney, 1995), and Performance Adjusted Model (Kothari, Leone, \& Wasley, 2005), focus on total accruals and they light up question marks in the aspects 
of model specification and unbiasedness in the minds of many researchers (Christodoulou, Ma, \& Vasnev, 2018; Jackson, 2018). As an alternative to aggregate accrual methods, some researchers have taken specific accounts for estimating discretionary accruals (Beneish, 1997; Giedt, 2018; Wahlen, 1994). Especially, cross-country research is more open to the risk of over-under estimation of discretionary accruals and, thus, may lead to biased models. Furthermore, it may be beneficial to check for industrial differences as each industry has its own business practice, and combining companies from different industries into the same basket without any control variable may lead to biased and inefficient results.

In this study, we aim to test some essential points of discretionary accruals, and we will use the financial information of companies from the Gulf Cooperation Council (GCC) countries. We will firstly test, among cash flow and balance sheet approaches, which type of total accruals provide better results. We will also compare the power of JM, MJM, and PMM. In the next stage, we will examine the necessity of control variables for countries. Further, we will test two groups of industries to add to the models. In the end, we will test an aggregate model that includes country and industry control variables.

\section{Earnings Management Models}

Several researchers in the earnings management field consider accruals as the key to manipulating earnings. Earnings may be manipulated through revenues and/or expenses that do not need a cash inflow/outflow because otherwise, one should exercise power on cash to adjust for manipulation. However, accruals are easier to manipulate than cash. Hence, researchers focus on accruals.

In the models using accruals, researchers calculate the magnitude of earnings management by taking the difference between total accruals reported in companies' financial reports and estimated accruals as a function of various measures. Total accruals are derived in two ways: the cash flow approach and the balance sheet approach. In the cash flow approach (Cohen \& Zarowin, 2010; Kuo, Ning, \& Song, 2014; Zang, 2012; Doukakis, 2014; Nguyen \& Duong, 2019), total accruals are computed as the difference between income before extraordinary items and operating cash flows. In the balance sheet approach (Healy, 1985; Jones, 1991; Kothari et al., 2005; Dang \& Tran, 2019; Dang, Nguyen, \& Tran, 2020), total accruals are calculated using the current assets and current liabilities. Hribar and Collins (2002) state the cash flow approach provides more accurate results compared to the balance sheet approach.

$$
\frac{A C C R_{-} C F_{i, t}}{T A_{i, t-1}}=\frac{E B X I_{i, t}}{T A_{i, t-1}}-\frac{O C F_{i, t}}{T A_{i, t-1}} \quad(\text { Cash Flow Approach })
$$

$$
\begin{aligned}
& \frac{A C C R_{-} B S_{i, t}}{T A_{i, t-1}}=\frac{\Delta C A_{i, t}}{T A_{i, t-1}}-\frac{\Delta \operatorname{Cash}_{i, t}}{T A_{i, t-1}}-\frac{\Delta C L_{i, t}}{T A_{i, t-1}} \\
& +\frac{\Delta S T D_{i, t}}{T A_{i, t-1}}-\frac{D e p_{i, t}}{T A_{i, t-1}} \quad \begin{array}{r}
\text { (Balance Sheet } \\
\text { Approach) }
\end{array}
\end{aligned}
$$

ACCR CF : Total Accruals using Cash Flow Approach ACCR_BS : Total Accruals using Balance Sheet Approach

TA : Total Assets

EBXI : Earnings Before Extraordinary Items

OCF : Operating Cash Flows

$\triangle \mathrm{CA} \quad:$ Change in Current Assets

$\Delta$ Cash $\quad$ : Change in Cash and Equivalents

$\triangle \mathrm{CL} \quad$ : Change in Current Liabilities

$\triangle$ STD $\quad$ : Change in Short-Term Debt and Current Portion of Long-Term Debt

Dep : Depreciation Expense

i : firm identifier

t $\quad$ : time identifier in years.

In the literature, we can see many different methods using accruals; these methods vary depending on the purpose of study, industries in which the companies operate, data availability, etc. Some models use total accruals (Healy, 1985; DeAngelo, 1986; Jones, 1991; Dechow et al., 1995; Kothari et al., 2005) as a proxy yet, some others use specific accruals such as McNichols and Wilson (1988), Beneish (1997 and 1999), and Beaver and McNichols (1998). Another point to consider in literature is the types of industries in which the companies subject to research belong to. Due to the nature of companies such as financial companies and non-financial companies, researchers have developed different models, and we can observe a dominance of research focusing on non-financial companies and leading models in the literature that are designed for this type of companies.

Healy (1985) has written one of the earliest studies on earnings management using discretionary accruals. He focused on CEO compensation and the tendency to manipulate earnings. Healy (1985) firstly found total accruals and then estimated non-discretionary accruals with a model. In the end, he took the difference between total accruals and non-discretionary accruals to find discretionary accruals. This model is one of the earliest models in the literature using discretionary accruals. In his Model, Healy took the difference in accruals between periods, as a measure of discretionary accruals. DeAngelo (1986) has also made one of the earliest contributions in this field. DeAngelo (1986) took management buyouts and earnings management relationships into consideration, suggesting that, in the period of buyouts, management might tend to reduce earnings to decrease share prices. She also indicated 
that after the buyout period, they would manipulate earnings in an upward direction to smooth income in total. Hence, total discretionary accruals in two periods would be zero. Like, Healy (1985), DeAngelo (1986) assumed discretionary accrual as the change in total accrual between consecutive periods.

Another early model we will discuss is the Jones Model. Jones (1991) aimed to investigate the relationship between import quotas and companies' tendency to report lower income before investigations and decisions of import quotas. Jones' model differed from its predecessors in a way that it estimated non-discretionary accruals as a function of change in revenues, depreciation, and assets of the company. The equation she built in her work follows:

$$
\begin{aligned}
\frac{N D_{-} A C C R_{i, t}}{T A_{i, t-1}}=\beta_{0}+ & \beta_{1} \frac{1}{T A_{i, t-1}}+\beta_{2} \frac{\Delta R e v_{i, t}}{T A_{i, t-1}} \\
& +\beta_{3} \frac{P P E_{i, t}}{T A_{i, t-1}}+\varepsilon_{i, t}
\end{aligned}
$$

$\begin{array}{ll}\text { ND_ACCR: } & \text { Non-Discretionary Accruals } \\ \text { TA: } & \text { Total Assets } \\ \text { AREV: } & \text { Change in Revenue } \\ \text { PPE: } & \text { Property Plant and Equipment }\end{array}$

She took the change in Revenue and Net Property Plant and Equipment as the explanatory variables in the function and estimated accruals with this equation. All variables are divided to lagged total assets in order to reduce variance and for the purpose of scaling.

Dechow et al. (1995) have published an article that takes many preceding models into account. They have applied tests for the power of models and made comparisons; also, they made a modification in the Jones Model. Instead of using the change in revenues, they subtracted change in receivables from a change in revenues. They argue that including change in receivables to the model would reduce specification bias and would provide more robust results. They also suggest that the Jones Model has ignored the effect of receivables in the model because an attempt to manipulate revenues would result in a change in receivables as well. This model is called as Modified Jones Model, and after its introduction to literature, it has been a dominant model used by researchers. It is still the study with the highest citation of the field in Google scholar with more than 9,500 citations as of May 2020.

The Modified Jones Model (MJM) is presented below:

$$
\begin{aligned}
\frac{N D_{-} A C C R_{i, t}}{T A_{i, t-1}}=\beta_{0} & +\beta_{1} \frac{1}{T A_{i, t-1}}+\beta_{2} \frac{\Delta \boldsymbol{R e v}_{i, t}-\Delta \boldsymbol{R e c}_{i, t}}{T A_{i, t-1}} \\
& +\beta_{3} \frac{P P E_{i, t}}{T A_{i, t-1}}+\varepsilon_{i, t}
\end{aligned}
$$

Beneish (1997) introduced a model with specific measures instead of a total accrual approach. He took some different measures for estimating earnings management. The model brings seven different dimensions to detect earnings management, namely: ownership structure, capital structure, time the firm was listed, market performance, auditor independence, sales growth, and positive accruals in previous periods.

In 2005, Kothari, Leone, and Wasley introduced a new variable to the Modified Jones Model. To control for the changes in companies' financial performance, they added ROA of companies to model. The reason was that, unless it is added, the firms with abnormal performances would be perceived as manipulating earnings. In addition to this new model, they also suggested to group companies with similar financial performance and matching each company with its group to detect discretionary accruals. Their work has a high impact and replaced the Modified Jones model in proceeding studies for application.

$$
\begin{aligned}
\frac{N D_{-} A C C R_{i, t}}{T A_{i, t-1}}=\beta_{0} & +\beta_{1} \frac{1}{T A_{i, t-1}}+\beta_{2} \frac{\Delta \operatorname{Rev}_{i, t}-\Delta \operatorname{Rec}_{i, t}}{T A_{i, t-1}} \\
& +\beta_{3} \frac{P P E_{i, t}}{T A_{i, t-1}}+\boldsymbol{R} \boldsymbol{O} A_{i, t}+\varepsilon_{i, t}
\end{aligned}
$$

Adding ROA variable, not only controls for variance, causing financial performance, but it reduces heteroskedasticity, and the model is better specified as well.

Roychowdhury (2006) has contributed to earnings management literature by introducing a model to estimate real earnings management practices. The study focuses on companies around zero earning threshold, and he investigated whether or not these companies manipulate earnings with real activities. For this purpose, Roychowdhury used three proxies to estimate real activity manipulation, cash flows from operations, discretionary expenses, and production costs. He found evidence that executives manipulate earnings with real activities to avoid losses.

Cohen, Dey, and Lys (2008) also worked on real activity earnings management. In their work, they found that accrual-based manipulation was more frequent in the PreSOX era, whereas companies tend to manipulate earnings using real activities in the post-SOX era. To determine real activity earnings management, they selected cash flows, discretionary expenses, and production costs, and they construct a model to find abnormal changes in these variables, and they determine the level of manipulation. In the last decade, this model, along with accrual models have an essential attraction. 


\section{Studies on Earnings Management in the GCC Countries}

In the literature, there are very few recent studies, which are investigating the earnings management practices of the non-financial companies in the GCC counties, comparatively. Most of the studies are based on an individual country in the GCC region. The earnings management literature shows that the studies are analyzing the effects of different factors on EM. For example, Al-Thuneibat, Al-Angari, and Al-Saad (2016) studied the relationship between corporate governance and EM in Saudi Arabia and Alareeni (2018a) investigated the same relationship in Bahrain, Farooq and AbdelBari (2015) investigated the effect of Shariah compliance on EM in selected MENA countries. Amin and Amin (2015) explained the impact of the adoption of International Financial Reporting Standards (IFRS) on EM in Iran, Bahrain, the UAE, and Saudi Arabia. Gerged, Al-Haddad, and Al-Hajri (2020) investigated corporate environmental disclosures and EM in Kuwait. Some studies about the auditing related factors that affect the EM, such as audit quality in Saudi Arabia (Habbash \& Alghamdi, 2017), and audit committee characteristics in Bahrain (Juhmani, 2017). Alareeni (2018b) investigated the effect of the firm-specific characteristics on the EM in GCC countries. Baatour, Othman \& Hussainey (2017) investigated the impact of multiple directorships on EM in Saudi Arabia. Al-Amri, Al Shidi, Al Busaidi, and Akguc (2017) analyzed the relationship between ownership structure and EM in GCC Countries, and Baatour and Othman (2016) explained the influence of the legal system and economic freedom on EM in MENA countries.

The studies on the earnings management for the nonmanufacturing firms in GCC countries have applied different models to estimate EM. Some studies only measured the accrual earnings management or real earnings management in their research, while some others utilized the results of both approaches in their analysis. In the literature, most of the EM studies about non-manufacturing firms in GCC countries used accrual EM models. Gerged et al. (2020) and Habbash and Alghamdi (2017) implemented Kothari's Model (Kothari et al. 2005) to estimate EM. Farooq and AbdelBari (2015), Alareeni (2018a, 2018b), Amin and Amin (2015), Baatour and Othman (2016) Al-Thuneibat et al. (2016), and Juhmani (2017) used Modified Jones Model (Dechow et al., 1995) of accrual earnings management. Baatour et al. (2017) utilized the Jones (1991) accrual EM model. Amin and Amin (2015) also implemented the model developed by Francis,Olsson, and Schipper (2008). On the other hand, Baatour and Othman (2016), and Al-Amri et al. (2017) used Roychowdhury's (2006) Model of the real EM approach.
Habbash and Alghamdi (2017), Baatour et al. (2017), and Al-Thuneibat et al. (2016) followed the cash flows approach; while Alareeni (2018a, 2018b), Juhmani (2017), Baatour and Othman (2016), Farooq and AbdelBari (2015), Amin and Amin (2015), and Gerged et al. (2020) followed the balance sheet approach to calculate the accruals.

\section{Data}

We selected non-financial companies that are operating and listed in GCC countries, namely, Bahrain (BA), Kuwait (KW), Oman (OM), Qatar (QA), Saudi Arabia (SA), and United Arab Emirates (UAE). We excluded financial companies as their operations and nature are quite different than non-financial companies, and taking them together would deteriorate the efficiency of tests. As a second step, we eliminated companies with missing data. We also eliminated outlier companies. In the end, we had 319 companies for five years (2014-2018). However, we need the variable "lagged asset" for our models; therefore, we used some data from 2013, but it is not included in tests. Our data consists of 15 companies from Bahrain, 55 companies from Kuwait, 72 companies from Oman, 20 companies from Qatar, 114 companies from Saudi Arabia, and 43 companies from United Arab Emirates. Depending on broad classification of industries companies are distributed as follows: 77 companies for Basic Materials, 47 companies for Consumer Cyclicals, 58 companies for Consumer Non-Cyclicals, 24 companies for Energy, 14 companies for Healthcare, 64 companies for Industrials, 5 companies for Technology, 16 companies for Telecommunication, and 14 companies for Utilities. In narrow classification of industries, companies are distributed as 270 companies for Production, 14 companies for RetailWholesale, and 35 companies for Service.

\section{Methodology}

We aim to examine the power of different models and variables in estimating accruals in GCC countries. As mentioned in the literature, total accruals are derived in two ways, the cash flow approach and the balance sheet approach. At this point, we investigate the existence and, if any, the magnitude of difference between these approaches. To serve this objective, firstly, we separated models into two main groups. The first group takes a cash flow approach for the calculation of total accruals. In the second group, total accruals are calculated using the "Balance Sheet Approach." Using these two approaches, we calculated two groups of dependent variables, and we constructed our models using these two groups.

In the next step, we determined models to compare, and we conducted our analysis by taking three wellknown and widely used models in the literature to estimate 
Non-Discretionary Accruals. These models are Jones Model (JM) by Jones (1991), Modified Jones Model (MJM) by Dechow et al. (1995), and Performance Matched Model (PMM) by Kothari et al. (2005). Additionally, because of the characteristics of the dataset, we added dummy variables to our models for controlling country-specific and industryspecific variances. We also ran the models without dummies to see whether they have a significant effect on the power of models.

The models and variables are presented below.

Model 1:

$$
\begin{array}{r}
\frac{N D_{-} A C C R_{-} C F_{i, t}}{T A_{i, t-1}}=\beta_{0}+\beta_{1} \frac{1}{T A_{i, t-1}}+\beta_{2} \frac{\Delta \operatorname{Rev}_{i, t}}{T A_{i, t-1}} \\
+\beta_{3} \frac{P P E_{i, t}}{T A_{i, t-1}}+\varepsilon_{i, t}
\end{array}
$$

Model 2:

$$
\begin{aligned}
\frac{N D_{-} A C C R_{-} C F_{i, t}}{T A_{i, t-1}} & =\beta_{0}+\beta_{1} \frac{1}{T A_{i, t-1}} \\
& +\beta_{2} \frac{\Delta R e v_{i, t}-\Delta R e c_{i, t}}{T A_{i, t-1}} \\
& +\beta_{3} \frac{P P E_{i, t}}{T A_{i, t-1}}+\varepsilon_{i, t}
\end{aligned}
$$

Model 3:

$$
\begin{aligned}
\frac{N D_{-} A C C R_{-} C F_{i, t}}{T A_{i, t-1}}= & \beta_{0}+\beta_{1} \frac{1}{T A_{i, t-1}} \\
& +\beta_{2} \frac{\Delta R e v_{i, t}-\Delta R e c_{i, t}}{T A_{i, t-1}} \\
& +\beta_{3} \frac{P P E_{i, t}}{T A_{i, t-1}}+\beta_{4} R O A_{i, t}+\varepsilon_{i, t}
\end{aligned}
$$

Model 4:

$$
\begin{aligned}
\frac{N D_{-} A C C R_{-} C F_{i, t}}{T A_{i, t-1}}=\beta_{0} & +\beta_{1} \frac{1}{T A_{i, t-1}} \\
& +\beta_{2} \frac{\Delta R e v_{i, t}}{T A_{i, t-1}} \\
& +\beta_{3} \frac{P P E_{i, t}}{T A_{i, t-1}}+\alpha_{j} \text { DDum }_{i, t}+\varepsilon_{i, t}
\end{aligned}
$$

Model 5:

$$
\begin{aligned}
\frac{N D_{-} A C C R \_C F_{i, t}}{T A_{i, t-1}} & =\beta_{0}+\beta_{1} \frac{1}{T A_{i, t-1}} \\
& +\beta_{2} \frac{\Delta \operatorname{Rev}_{i, t}-\Delta \operatorname{Rec}_{i, t}}{T A_{i, t-1}} \\
& +\beta_{3} \frac{P P E_{i, t}}{T A_{i, t-1}}+\alpha_{j} \operatorname{CDum}_{i, t}+\varepsilon_{i, t}
\end{aligned}
$$

Model 6:

$$
\begin{aligned}
\frac{N D_{-} A C C R_{-} C F_{i, t}}{T A_{i, t-1}} & =\beta_{0}+\beta_{1} \frac{1}{T A_{i, t-1}} \\
& +\beta_{2} \frac{\Delta \operatorname{Rev}_{i, t}-\Delta \operatorname{Rec}_{i, t}}{T A_{i, t-1}}+\beta_{3} \frac{P P E_{i, t}}{T A_{i, t-1}} \\
& +\beta_{4} \operatorname{ROA}_{i, t}+\alpha_{j} \operatorname{CDum}_{i, t}+\varepsilon_{i, t}
\end{aligned}
$$

Model 7:

$$
\begin{array}{r}
\frac{N D_{-} A C C R_{-} C F_{i, t}}{T A_{i, t-1}}=\beta_{0}+\beta_{1} \frac{1}{T A_{i, t-1}}+\beta_{2} \frac{\Delta \operatorname{Rev}_{i, t}}{T A_{i, t-1}} \\
+\beta_{3} \frac{P P E_{i, t}}{T A_{i, t-1}}+\partial_{j} S_{D^{\prime}} \text { Dum }_{i, t}+\varepsilon_{i, t}
\end{array}
$$

Model 8:

$$
\begin{aligned}
\frac{N D_{-} A C C R \_C F_{i, t}}{T A_{i, t-1}} & =\beta_{0}+\beta_{1} \frac{1}{T A_{i, t-1}} \\
& +\beta_{2} \frac{\Delta \operatorname{Rev}_{i, t}-\Delta \operatorname{Rec}_{i, t}}{T A_{i, t-1}} \\
& +\beta_{3} \frac{P P E_{i, t}}{T A_{i, t-1}}+\partial_{j} \operatorname{S1Dum}_{i, t}+\varepsilon_{i, t}
\end{aligned}
$$

Model 9:

$$
\begin{aligned}
\frac{N D_{-} A C C R_{-} C F_{i, t}}{T A_{i, t-1}} & =\beta_{0}+\beta_{1} \frac{1}{T A_{i, t-1}} \\
& +\beta_{2} \frac{\Delta \operatorname{Rev}_{i, t}-\Delta \operatorname{Rec}_{i, t}}{T A_{i, t-1}}+\beta_{3} \frac{P P E_{i, t}}{T A_{i, t-1}} \\
& +\beta_{4} R O A_{i, t}+\partial_{j} S 1 \operatorname{Dum}_{i, t}+\varepsilon_{i, t}
\end{aligned}
$$


Model 10:

$$
\begin{aligned}
\frac{N D_{-} A C C R_{-} C F_{i, t}}{T A_{i, t-1}} & =\beta_{0}+\beta_{1} \frac{1}{T A_{i, t-1}} \\
& +\beta_{2} \frac{\Delta \operatorname{Rev}_{i, t}}{T A_{i, t-1}}+\beta_{3} \frac{P P E_{i, t}}{T A_{i, t-1}} \\
& +\partial_{j} S 2 \operatorname{Dum}_{i, t}+\varepsilon_{i, t}
\end{aligned}
$$

Model 11:

$$
\begin{aligned}
\frac{N D_{-} A C C R_{-} C F_{i, t}}{T A_{i, t-1}} & =\beta_{0}+\beta_{1} \frac{1}{T A_{i, t-1}} \\
& +\beta_{2} \frac{\Delta R e v_{i, t}-\Delta R e c_{i, t}}{T A_{i, t-1}} \\
& +\beta_{3} \frac{P P E_{i, t}}{T A_{i, t-1}}+\partial_{j} S 2 \operatorname{Dum}_{i, t}+\varepsilon_{i, t}
\end{aligned}
$$

Model 12:

$$
\begin{aligned}
\frac{N D_{-} A C C R_{-} C F_{i, t}}{T A_{i, t-1}} & =\beta_{0}+\beta_{1} \frac{1}{T A_{i, t-1}} \\
& +\beta_{2} \frac{\Delta \operatorname{Rev}_{i, t}-\Delta \operatorname{Rec}_{i, t}}{T A_{i, t-1}}+\beta_{3} \frac{P P E_{i, t}}{T A_{i, t-1}} \\
& +\beta_{4} \operatorname{ROA}_{i, t}+\partial_{j} S 2 \operatorname{Dum}_{i, t}+\varepsilon_{i, t}
\end{aligned}
$$

Model 13:

$$
\begin{aligned}
\frac{N D_{-} A C C R \_C F_{i, t}}{T A_{i, t-1}} & =\beta_{0}+\beta_{1} \frac{1}{T A_{i, t-1}} \\
+ & \beta_{2} \frac{\Delta \operatorname{Rev}_{i, t}}{T A_{i, t-1}}+\beta_{3} \frac{P P E_{i, t}}{T A_{i, t-1}} \\
& +\alpha_{j} \text { DDum }_{i, t}+\partial_{j} S 2 \text { Dum }_{i, t}+\varepsilon_{i, t}
\end{aligned}
$$

Model 14:

$$
\begin{aligned}
\frac{N D_{-} A C C R \_C F_{i, t}}{T A_{i, t-1}} & =\beta_{0}+\beta_{1} \frac{1}{T A_{i, t-1}} \\
& +\beta_{2} \frac{\Delta \operatorname{Rev}_{i, t}-\Delta \operatorname{Rec}_{i, t}}{T A_{i, t-1}} \\
& +\beta_{3} \frac{P P E_{i, t}}{T A_{i, t-1}}+\alpha_{j} \operatorname{CDum}_{i, t} \\
& +\partial_{j} \operatorname{SDum}_{i, t}+\varepsilon_{i, t}
\end{aligned}
$$

Model 15:

$$
\begin{aligned}
\frac{N D_{-} A C C R_{-} C F_{i, t}}{T A_{i, t-1}} & =\beta_{0}+\beta_{1} \frac{1}{T A_{i, t-1}} \\
& +\beta_{2} \frac{\Delta \operatorname{Rev}_{i, t}-\Delta \operatorname{Rec}_{i, t}}{T A_{i, t-1}} \\
& +\beta_{3} \frac{P P E_{i, t}}{T A_{i, t-1}}+\beta_{4} \operatorname{ROA}_{i, t} \\
& +\alpha_{j} \text { CDum }_{i, t}+\partial_{j} \text { S2Dum }_{i, t}+\varepsilon_{i, t}
\end{aligned}
$$

Model 16:

$$
\begin{aligned}
\frac{N D_{-} A C C R_{-} B S_{i, t}}{T A_{i, t-1}} & =\beta_{0}+\beta_{1} \frac{1}{T A_{i, t-1}} \\
+ & \beta_{2} \frac{\Delta R e v_{i, t}}{T A_{i, t-1}}+\beta_{3} \frac{P P E_{i, t}}{T A_{i, t-1}}+\varepsilon_{i, t}
\end{aligned}
$$

Model 17:

$$
\begin{aligned}
& \frac{N D_{-} A C C R_{-} B S_{i, t}}{T A_{i, t-1}}=\beta_{0}+\beta_{1} \frac{1}{T A_{i, t-1}} \\
& +\beta_{2} \frac{\Delta \operatorname{Rev}_{i, t}-\Delta \operatorname{Rec}_{i, t}}{T A_{i, t-1}} \\
& +\beta_{3} \frac{P P E_{i, t}}{T A_{i, t-1}}+\varepsilon_{i, t}
\end{aligned}
$$

Model 18:

$$
\begin{aligned}
\frac{N D_{-} A C C R_{-} B S_{i, t}}{T A_{i, t-1}} & =\beta_{0}+\beta_{1} \frac{1}{T A_{i, t-1}} \\
& +\beta_{2} \frac{\Delta R e v_{i, t}-\Delta R e c_{i, t}}{T A_{i, t-1}} \\
& +\beta_{3} \frac{P P E_{i, t}}{T A_{i, t-1}}+\beta_{4} R O A_{i, t}+\varepsilon_{i, t}
\end{aligned}
$$

Model 19:

$$
\begin{aligned}
\frac{N D_{-} A C C R_{-} B S_{i, t}}{T A_{i, t-1}} & =\beta_{0}+\beta_{1} \frac{1}{T A_{i, t-1}} \\
& +\beta_{2} \frac{\Delta \operatorname{Rev}_{i, t}}{T A_{i, t-1}}+\beta_{3} \frac{P P E_{i, t}}{T A_{i, t-1}} \\
& +\alpha_{j} \text { CDum }_{i, t}+\varepsilon_{i, t}
\end{aligned}
$$


Model 20:

$$
\begin{aligned}
\frac{N D_{-} A C C R_{-} B S_{i, t}}{T A_{i, t-1}} & =\beta_{0}+\beta_{1} \frac{1}{T A_{i, t-1}} \\
& +\beta_{2} \frac{\Delta R e v_{i, t}-\Delta R e c_{i, t}}{T A_{i, t-1}} \\
& +\beta_{3} \frac{P P E_{i, t}}{T A_{i, t-1}}+\alpha_{j} \text { CDum }_{i, t}+\varepsilon_{i, t}
\end{aligned}
$$

Model 21:

$$
\begin{aligned}
\frac{N D_{-} A C C R_{-} B S_{i, t}}{T A_{i, t-1}} & =\beta_{0}+\beta_{1} \frac{1}{T A_{i, t-1}} \\
& +\beta_{2} \frac{\Delta \operatorname{Rev}_{i, t}-\Delta \operatorname{Rec}_{i, t}}{T A_{i, t-1}}+\beta_{3} \frac{P P E_{i, t}}{T A_{i, t-1}} \\
& +\beta_{4} \operatorname{ROA}_{i, t}+\alpha_{j} \operatorname{CDum}_{i, t}+\varepsilon_{i, t}
\end{aligned}
$$

Model 22:

$$
\begin{aligned}
\frac{N D_{-} A C C R_{-} B S_{i, t}}{T A_{i, t-1}} & =\beta_{0}+\beta_{1} \frac{1}{T A_{i, t-1}} \\
+ & \beta_{2} \frac{\Delta \operatorname{Rev}_{i, t}}{T A_{i, t-1}}+\beta_{3} \frac{P P E_{i, t}}{T A_{i, t-1}} \\
+ & \partial_{j} S 1 \operatorname{Dum}_{i, t}+\varepsilon_{i, t}
\end{aligned}
$$

Model 23:

$$
\begin{aligned}
\frac{N D_{-} A C C R_{-} B S_{i, t}}{T A_{i, t-1}} & =\beta_{0}+\beta_{1} \frac{1}{T A_{i, t-1}} \\
& +\beta_{2} \frac{\Delta \operatorname{Rev}_{i, t}-\Delta \operatorname{Rec} c_{i, t}}{T A_{i, t-1}} \\
& +\beta_{3} \frac{P P E_{i, t}}{T A_{i, t-1}}+\partial_{j} S 1 \text { Dum }_{i, t}+\varepsilon_{i, t}
\end{aligned}
$$

Model 24:

$$
\begin{aligned}
\frac{N D_{-} A C C R_{-} B S_{i, t}}{T A_{i, t-1}} & =\beta_{0}+\beta_{1} \frac{1}{T A_{i, t-1}} \\
& +\beta_{2} \frac{\Delta \operatorname{Rev}_{i, t}-\Delta \operatorname{Rec}_{i, t}}{T A_{i, t-1}} \\
& +\beta_{3} \frac{P P E_{i, t}}{T A_{i, t-1}}+\beta_{4} R O A_{i, t} \\
& +\partial_{j} S 1 \operatorname{Dum}_{i, t}+\varepsilon_{i, t}
\end{aligned}
$$

Model 25:

$$
\begin{aligned}
\frac{N D_{-} A C C R_{-} B S_{i, t}}{T A_{i, t-1}} & =\beta_{0}+\beta_{1} \frac{1}{T A_{i, t-1}} \\
& +\beta_{2} \frac{\Delta \operatorname{Rev}_{i, t}}{T A_{i, t-1}}+\beta_{3} \frac{P P E_{i, t}}{T A_{i, t-1}} \\
& +\partial_{j} S 2 \operatorname{Dum}_{i, t}+\varepsilon_{i, t}
\end{aligned}
$$

Model 26:

$$
\begin{aligned}
\frac{N D_{-} A C C R_{-} B S_{i, t}}{T A_{i, t-1}} & =\beta_{0}+\beta_{1} \frac{1}{T A_{i, t-1}} \\
& +\beta_{2} \frac{\Delta \operatorname{Rev}_{i, t}-\Delta \operatorname{Rec}_{i, t}}{T A_{i, t-1}} \\
& +\beta_{3} \frac{P P E_{i, t}}{T A_{i, t-1}}+\partial_{j} \text { S2Dum }_{i, t}+\varepsilon_{i, t}
\end{aligned}
$$

Model 27:

$$
\begin{aligned}
\frac{N D_{-} A C C R_{\_} B S_{i, t}}{T A_{i, t-1}} & =\beta_{0}+\beta_{1} \frac{1}{T A_{i, t-1}} \\
& +\beta_{2} \frac{\Delta \operatorname{Rev}_{i, t}-\Delta \operatorname{Rec}_{i, t}}{T A_{i, t-1}} \\
& +\beta_{3} \frac{P P E_{i, t}}{T A_{i, t-1}}+\beta_{4} R O A_{i, t} \\
& +\partial_{j} S 2 \operatorname{Dum}_{i, t}+\varepsilon_{i, t}
\end{aligned}
$$

Model 28:

$$
\begin{aligned}
\frac{N D_{-} A C C R \_B S_{i, t}}{T A_{i, t-1}} & =\beta_{0}+\beta_{1} \frac{1}{T A_{i, t-1}} \\
& +\beta_{2} \frac{\Delta \operatorname{Rev}_{i, t}}{T A_{i, t-1}}+\beta_{3} \frac{P P E_{i, t}}{T A_{i, t-1}} \\
& +\alpha_{j} \text { CDum }_{i, t}+\partial_{j} S \text { Dum }_{i, t}+\varepsilon_{i, t}
\end{aligned}
$$

Model 29:

$$
\begin{aligned}
\frac{N D_{-} A C C R \_B S_{i, t}}{T A_{i, t-1}} & =\beta_{0}+\beta_{1} \frac{1}{T A_{i, t-1}} \\
& +\beta_{2} \frac{\Delta \operatorname{Rev}_{i, t}-\Delta \operatorname{Rec}_{i, t}}{T A_{i, t-1}} \\
& +\beta_{3} \frac{P P E_{i, t}}{T A_{i, t-1}}+\alpha_{j} \operatorname{CDum}_{i, t} \\
& +\partial_{j} \operatorname{SDum}_{i, t}+\varepsilon_{i, t}
\end{aligned}
$$


Model 30:

$$
\begin{aligned}
\frac{N D_{-} A C C R \_B S_{i, t}}{T A_{i, t-1}} & =\beta_{0}+\beta_{1} \frac{1}{T A_{i, t-1}} \\
& +\beta_{2} \frac{\Delta \operatorname{Rev}_{i, t}-\Delta \operatorname{Rec}_{i, t}}{T A_{i, t-1}} \\
& +\beta_{3} \frac{P P E_{i, t}}{T A_{i, t-1}}+\beta_{4} R O A_{i, t} \\
& +\alpha_{j} \text { CDum }_{i, t}+\partial_{j} S_{2} \text { Dum }_{i, t}+\varepsilon_{i, t}
\end{aligned}
$$

ND_ACCR_CF
ND_ACCR_BS

TA

$\triangle \mathrm{REV}$

$\triangle \mathrm{REC}$

PPE

ROA

CDum

S1Dum

S2Dum

$\varepsilon$
$\mathrm{i}$
$\mathrm{t}$

These models are derived, not only to test the differences between renowned models, but also to see whether there are significant differences between models with dummies. To see these differences: we constructed the following hypotheses:

H1: Total accruals derived from the Cash Flow Approach provide more accurate and less variant results than those derived from Balance Sheet Approach.

H2: PMM has the highest explanatory power and significance among the models, followed by MJM and JM, consecutively.

H3: Adding country dummies have significant effects on the explanatory power of the models.

H4: Adding a broader group of industry dummies based on business classification has better explanatory power than adding a narrow group of classical industrial classification.
H5: Adding country and industry-specific dummies together has a significant positive effect on the power of the model.

To test Hypothesis 1 we constructed 15 models for each alternative. Models 1 to 15 take total accruals derived from the Cash Flow Approach (ACCR_CF), and models 16 to 30 take total accruals derived from the Balance Sheet Approach (ACCR_BS) (Table 1). It is worth mentioning the difference between Total Accruals in equations 1 and 2, and Non-Discretionary Accruals, which are stated as dependent variables in models. The preceding two are calculated accruals, which are derived from financial statements of companies using cash flow or balance sheet approaches.

The accruals in models (ND_ACCR_CF and ND_ ACCR_BS) are estimated non-discretionary components of total accruals using the corresponding models. Discretionary Accruals (D_ACCR) are derived from the difference between Total Accruals and Non-Discretionary accruals.

$$
D \_A C C R=A C C R-N D \_A C C R
$$

(Equation 3)

To test for hypotheses compared to $\mathrm{R}^{2}$ and Overall Significances of models.

Our data has both panel characteristics and includes country data for over five years. Hence, we used panel data regression models, and we conducted tests for an accurate result. We conducted the Hausman Test and Breusch and Pagan Lagrangian Multiplier test to choose the bestfitting model for our dataset. Additionally, we checked for homoscedasticity and multicollinearity to have more efficient results. They will be mentioned in the analysis section.

We constructed thirty models to test the effects of several aspects of discretionary accruals. First, we made a classification due to dependent variables, ACCR-CF, and ACCR_BS. Each dependent variable is included in 15 models. Secondly, we wanted to see which discretionary accrual model provides the best and efficient results among the Jones model, the Modified Jones Model, and Performance Matched Model. Further, we added country dummies and tested their overall significances in models. Then we tested the industrial differences. We took two different industry classifications and tested them separately, and finally, we added country and industry dummies together to the model and tested its significance. For each of these tests, we constructed hypotheses. The next section delivers these results. 
Table 1: Regression Results of the Models Based on the Cash Flows Approach

\begin{tabular}{|c|c|c|c|c|c|c|c|c|c|c|}
\hline \multicolumn{3}{|c|}{$\begin{array}{l}\text { Models Based on the Cash } \\
\text { Flows Approach }\end{array}$} & \multirow{2}{*}{\begin{tabular}{c|} 
Constant \\
$-0.014^{* \star *}$
\end{tabular}} & \multirow{2}{*}{$\begin{array}{c}\text { Asset } \\
2498\end{array}$} & \multirow{2}{*}{\begin{tabular}{|c|} 
PPE \\
$-0.051^{* \star *}$ \\
\end{tabular}} & \multirow{2}{*}{$\frac{\Delta \operatorname{Rev}}{0.038^{* *}}$} & \multirow[t]{2}{*}{$\begin{array}{l}\Delta \operatorname{Rev}- \\
\Delta \operatorname{Rec}\end{array}$} & ROA & \multirow{2}{*}{$\begin{array}{c}\mathbf{R}^{\mathbf{2}} \\
0.0890\end{array}$} & \multirow{2}{*}{\begin{tabular}{|c|}
$\begin{array}{c}\text { Overall } \\
\text { significance }\end{array}$ \\
$38.80^{\star * *}$ \\
\end{tabular}} \\
\hline \multirow{3}{*}{$\begin{array}{l}\text { No } \\
\text { dummy }\end{array}$} & Jones & Model 1 & & & & & & & & \\
\hline & $\begin{array}{c}\text { Modified } \\
\text { Jones }\end{array}$ & Model 2 & $-0.016^{\star \star \star}$ & 35115 & $-0.046^{\star \star \star}$ & & $-0.040^{*}$ & & 0.0625 & $35.57^{* * *}$ \\
\hline & Kothari & Model 3 & $-0.031^{* * *}$ & 92323 & $-0.052^{* * *}$ & & $-0.061^{* \star}$ & $0.393^{* * *}$ & 0.1562 & $62.81^{* \star *}$ \\
\hline \multirow{3}{*}{$\begin{array}{l}\text { Country } \\
\text { dummy }\end{array}$} & Jones & Model 4 & $-0.016^{*}$ & 15494 & $-0.050^{* * *}$ & $0.037^{* *}$ & & & 0.1161 & $1.14^{* * *}$ \\
\hline & $\begin{array}{l}\text { Modified } \\
\text { Jones }\end{array}$ & Model 5 & $-0.018^{\star *}$ & 51535 & $-0.046^{\star * *}$ & & $-0.041^{*}$ & & 0.0917 & $45.14^{* * *}$ \\
\hline & Kothari & Model 6 & $-0.026^{\star \star *}$ & 98273 & $-0.050^{\star \star *}$ & & $-0.061^{\text {** }}$ & $0.391^{* * *}$ & 0.1974 & $72.45^{\star \star *}$ \\
\hline \multirow{3}{*}{$\begin{array}{l}\text { Industry- } \\
\text { narrow } \\
\text { dummy }\end{array}$} & Jones & Model 7 & $-0.031^{* *}$ & -16433 & $-0.050^{* * *}$ & $0.038^{* *}$ & & & 0.1031 & $4366^{* * *}$ \\
\hline & $\begin{array}{c}\text { Modified } \\
\text { Jones }\end{array}$ & Model 8 & $-0.033^{\star \star}$ & 16066 & $-0.046^{\star \star \star}$ & & $-0.040^{*}$ & & 0.0767 & $41.11^{\star \star \star}$ \\
\hline & Kothari & Model 9 & $-0.048^{* * *}$ & 78727 & $-0.053^{\star \star *}$ & & $-0.061^{* *}$ & $0.393^{* * *}$ & 0.1979 & $69.91^{* * *}$ \\
\hline \multirow{3}{*}{$\begin{array}{l}\text { Industry- } \\
\text { broad } \\
\text { dummy }\end{array}$} & Jones & Model 10 & $-0.018^{*}$ & -57833 & $-0.051^{* * *}$ & $0.042^{* *}$ & & & 0.2492 & $114.01^{* \star *}$ \\
\hline & $\begin{array}{l}\text { Modified } \\
\text { Jones }\end{array}$ & Model 11 & -( & -22992 & -0.0 & & -0.035 & & 0.2184 & 995 \\
\hline & Kothari & Model 12 & $-0.027^{* *}$ & 57181 & $-0.051^{* * *}$ & & $-0.059^{* *}$ & 0.380 & 0.2843 & $106.86^{* * *}$ \\
\hline \multirow{3}{*}{$\begin{array}{l}\text { Country } \\
\& \\
\text { industry- } \\
\text { broad }\end{array}$} & Jones & Model 13 & -0.021 & -51396 & $-0.049^{* * *}$ & $0.041^{* *}$ & & & 0.2838 & $136.64^{* * *}$ \\
\hline & $\begin{array}{c}\text { Modified } \\
\text { Jones }\end{array}$ & Model 14 & $-0.024^{\star}$ & -13031 & $-0.044^{* * *}$ & & -0.036 & & 0.2551 & $121.38^{* * *}$ \\
\hline & Kothari & Model 15 & $5^{* *}$ & 62417 & $-0.048^{* * *}$ & & $-0.059^{* *}$ & $0.376^{* * *}$ & 0.3071 & $131.56^{* * *}$ \\
\hline \multicolumn{3}{|c|}{$\begin{array}{l}\text { Models Based on the } \\
\text { Balance Sheet Approach }\end{array}$} & Constant & Asset & PPE & $\Delta \operatorname{Rev}$ & & ROA & $\mathbf{R}^{2}$ & $\begin{array}{c}\text { Overall } \\
\text { significance }\end{array}$ \\
\hline \multirow{3}{*}{$\begin{array}{l}\text { No } \\
\text { dummy }\end{array}$} & Jones & Model 16 & $-0.018^{\star * *}$ & 249786 & $-0.057^{* * *}$ & $0.064^{* *}$ & & & 0.0920 & $22.27^{* \star *}$ \\
\hline & \begin{tabular}{|c|}
$\begin{array}{c}\text { Modified } \\
\text { Jones }\end{array}$ \\
\end{tabular} & Model 17 & $-0.018^{* * *}$ & 272923 & $-0.054^{* * *}$ & & 0.009 & & 0.0694 & $15.23^{* * *}$ \\
\hline & Kothari & Model 18 & $-0.027^{\star \star *}$ & 319800 & $-0.056^{\star \star *}$ & & -0.006 & 0.2 & 0.1088 & $43.92^{* \star *}$ \\
\hline \multirow{3}{*}{$\begin{array}{l}\text { Country } \\
\text { dummy }\end{array}$} & Jones & Model 19 & $-0.016^{*}$ & 260268 & $-0.059^{* * *}$ & $0.064^{* *}$ & & & 0.0930 & $28.22^{* \star *}$ \\
\hline & $\begin{array}{c}\text { Modified } \\
\text { Jones }\end{array}$ & Model 20 & $-0.018^{* *}$ & 285687 & $-0.056^{* * *}$ & & 0.009 & & 0.0710 & $18.53^{* *}$ \\
\hline & Kothari & Model 21 & $-0.023^{\star *}$ & 329062 & $-0.057^{* * *}$ & & -0.005 & 0.203 & 0.1090 & $50.47^{\star *}$ \\
\hline \multirow{3}{*}{$\begin{array}{l}\text { Industry- } \\
\text { narrow } \\
\text { dummy }\end{array}$} & Jones & Model 22 & $-0.041^{* * *}$ & 239240 & $-0.062^{* * *}$ & $0.066^{* *}$ & & & 0.1317 & $24.69^{* * *}$ \\
\hline & $\begin{array}{c}\text { Modified } \\
\text { Jones }\end{array}$ & Model 23 & $-0.041^{\star * *}$ & 263141 & $-0.059^{\star * *}$ & & 0.009 & & 0.1065 & $17.14^{\star \star \star}$ \\
\hline & Kothari & Model 24 & $-0.050^{* * *}$ & 313885 & $-0.062^{\star \star *}$ & & -0.005 & $0.205^{\star}$ & 0.1478 & $46.17^{* \star *}$ \\
\hline \multirow{3}{*}{$\begin{array}{l}\text { Industry- } \\
\text { broad } \\
\text { dummy }\end{array}$} & Jones & Model 25 & 0.017 & 217315 & $-0.066^{* * *}$ & $0.068^{* *}$ & & & 0.2352 & $46.64^{* * *}$ \\
\hline & \begin{tabular}{|c|} 
Modified \\
Jones
\end{tabular} & Model 26 & 0.015 & 242179 & $-0.062^{* * *}$ & & 0.013 & & 0.2081 & $37.41^{* * *}$ \\
\hline & Kothari & Model 27 & 0.011 & 298952 & $-0.064^{* * *}$ & & -0.003 & 0.19 & 0.2401 & $66.96^{\star * \star}$ \\
\hline \multirow{3}{*}{$\begin{array}{l}\text { Country } \\
\& \\
\text { industry- } \\
\text { broad }\end{array}$} & Jones & Model 28 & 0.020 & 241887 & $-0.066^{* * *}$ & $0.068^{* * *}$ & & & 0.2395 & $61.58^{* * *}$ \\
\hline & $\begin{array}{c}\text { Modified } \\
\text { Jones }\end{array}$ & Model 29 & 0.018 & 268904 & & $-0.062^{\star \star \star}$ & 0.012 & & 0.2131 & $48.84^{\star \star \star}$ \\
\hline & Kothari & Model 30 & 0.017 & 324791 & $-0.063^{* * *}$ & & -0.004 & $0.197^{*}$ & \begin{tabular}{l|l}
$*$ & 0.2439 \\
\end{tabular} & $76.90^{* * *}$ \\
\hline
\end{tabular}


Before proceeding to the hypotheses results, it is necessary to state the methods used in regression procedures. We used STATA software for running regressions. Because of the nature of data, we face heteroskedasticity in results, which would harm the efficiency of our estimates. Hence, we used robust standard errors in models and to eliminate heteroskedasticity. We also checked for multicollinearity among independent variables, and we examined no perfect multicollinearity among regressors of the same model. According to the Hausman specification test and Breusch Pagan Lagrange Multiplier test results, we used a random effects panel regression model. We did not check for autocorrelation because our time dimension is relatively small (5 periods), which does not necessitate a test for autocorrelation.

\section{Results}

In this part of the study, the results and analysis will be delivered. Firstly, the descriptive statistics are analyzed, they are followed by regression results, and the hypotheses are tested and analyzed at the end of this section.

\subsection{Descriptive Statistics and Correlation Matrix}

Table 2 presents a summary statistic of variables. The dataset covers five years and 319 companies, which constitutes 1,595 observations. Accruals computed by the cash flow approach (ACCR_CF) are slightly higher than those computed via the balance sheet approach (ACCR_BS). It is worth reminding the fact here that all variables except ROA are divided to lagged total assets depending on the models. This would help reduce variance and thus provide more efficient results. Another point attracting our interest is the standard deviations of these two variables. ACCR_CF has relatively less deviation than ACCR_BS. However, as we tested the equality of means and variances, they do not present a significant difference.

Furthermore, both means are negative, leading us to the fact that cash flow from operations exceeds earnings before extraordinary items. This would result from two factors, either the companies do the transactions more cash-based, or there is a significant effect of accrual expenses in their income statements such as depreciation and amortization. The second point, which is worth mentioning, is PPE. It has an average of $43.9 \%$, implying that companies have almost $43 \%$ of net PPE in their composition of assets. ROA figure portrays a $4 \%$ average return for assets.

Correlations among the variables reveal significant relations between dependent and independent variables. ACCR_CF has a significant relation with $\triangle R E V$, $\triangle \mathrm{REV} \bar{\Delta} \mathrm{REC}, \mathrm{PPE}$, and ROA, whereas ACCR BS is significantly correlated with ASSET, $\triangle \mathrm{REV}, \mathrm{PPE}$, and ROA. Here PPE is negatively correlated with both dependent variables. This is caused by the effect of depreciation expenses. The more depreciation expense, the less income, and less net accruals. It is also important to point out that there is not a correlation of more than $80 \%$ among independent variables. This is important for the assumption of no perfect multicollinearity for regressions. There is one exception for this fact, and it is the correlation between $\triangle \mathrm{REV}$ and $\triangle \mathrm{REV} \triangle \mathrm{REC}(0.9264)$, yet it does not affect the regression because these two variables are not used in the same models they work as substitutes (Table 3).

\subsection{Regression Results}

Hypothesis 1 tests for the superiority of accruals derived from the cash flow approach and balance sheet approach for better goodness of fit and significance. Table 1 provides the $\mathrm{R}^{2}$ and overall significances of models for which the dependent variables were derived using both approaches. For instance, Model 1 and Model 16 uses the same independent variables; however, Model 1 uses Accruals (dependent variable) derived from Cash Flow Approach (CFS Approach), and Model 16 uses those derived from Balance Sheet Approach (BS Approach). In all duels, the CFS approach provides a higher $\mathrm{R}^{2}$, and overall significance is considerably higher. On the other hand, we did not observe any significant difference between the means and variances of these two variables.

Table 2: Descriptive Statistics

\begin{tabular}{|l|c|c|c|c|c|}
\hline Variable & Obs & Mean & St. Dev. & Min & Max \\
\hline ACCR_CF & 1,595 & -0.0358 & 0.0892 & -0.6598 & 0.8352 \\
\hline ACCR_BS & 1,595 & -0.0384 & 0.1068 & -1.2264 & 1.5351 \\
\hline Asset & 1,595 & $1.34 \mathrm{E}-08$ & $3.47 \mathrm{E}-08$ & $8.41 \mathrm{E}-12$ & $4.02 \mathrm{E}-07$ \\
\hline$\Delta \operatorname{Rev}$ & 1,595 & 0.0139 & 0.1690 & -1.3929 & 1.7853 \\
\hline$\Delta \operatorname{Rev}-\Delta \operatorname{Rec}$ & 1,595 & 0.0060 & 0.1595 & -1.3922 & 1.8317 \\
\hline PPE & 1,595 & 0.4391 & 0.2934 & 0.0001 & 2.8796 \\
\hline ROA & 1,595 & 0.0427 & 0.0970 & -0.9903 & 0.7993 \\
\hline
\end{tabular}


Table 3: Correlation Table

\begin{tabular}{|l|c|c|c|c|c|c|c|}
\hline & ACCR_CF & ACCR_BS & Asset & $\Delta$ Rev & $\Delta$ Rev- $\Delta$ Rec & PPE & ROA \\
\hline ACCR_CF & 1 & & & & & & \\
\hline ACCR_BS & $0.5252^{*}$ & 1 & & & & & \\
\hline Asset & -0.002 & $0.0781^{*}$ & 1 & & & & \\
\hline$\Delta \operatorname{Rev}$ & $0.0652^{*}$ & $0.0941^{*}$ & $0.0918^{*}$ & 1 & & & \\
\hline$\Delta \operatorname{Rev}-\Delta \operatorname{Rec}$ & $-0.0678^{*}$ & 0.011 & $0.0972^{*}$ & $0.9264^{*}$ & 1 & & \\
\hline PPE & $-0.1621^{*}$ & $-0.1374^{*}$ & $0.0730^{*}$ & $0.0999^{*}$ & $0.0903^{*}$ & 1 & 1 \\
\hline ROA & $0.3568^{*}$ & $0.1672^{*}$ & $-0.0732^{*}$ & $0.1758^{*}$ & $0.1190^{*}$ & 0.0338 & 1 \\
\hline
\end{tabular}

Table 4: Country Comparison (CFS \& BS Approaches)

\begin{tabular}{|c|c|c|}
\hline \multicolumn{3}{|c|}{ Models Using the Cash Flow Approach } \\
\hline Base Model & Country Dummy & F-Statistic \\
\hline Model 1 (JM) & Model 4 (JM) & $9.725^{* * *}$ \\
\hline Model 2 (MJM) & Model 5 (MJM) & $10.191^{* * *}$ \\
\hline Model 3 (PMM) & Model 6 (PMM) & $16.262^{\star * *}$ \\
\hline \multicolumn{3}{|c|}{ Models Using the Balance Sheet Approach } \\
\hline Base Model & Country Dummy & F-Statistic \\
\hline Model $16(\mathrm{JM})$ & Model $19(\mathrm{JM})$ & 0.3497 \\
\hline Model 17 (MJM) & Model 20 (MJM) & 0.5460 \\
\hline Model 18 (PMM) & Model 21 (PMM) & 0.0711 \\
\hline
\end{tabular}

In the Hypothesis 2, we took three major models in discretionary accruals literature, namely, Jones Model (JM), Modified Jones Model (MJM), and Performance Matched Model (PMM), and conducted a comparison. We expect that PMM has the highest significance and goodness of fit scores, and it should be followed by MJM, and we put JM to the last place in our considerations. The results were parallel to our expectations regarding PMM. It is, by far, the model with the highest explanatory power and significance compared to the other two models. However, our second expectation does not hold. MJM model has lower $\mathrm{R}^{2}$ and significance levels than JM.

Hypothesis 3 takes the country dummies into account. It is obvious that business practices may differ across countries. On the other hand, this difference may lose its significance for the countries bearing resemblance in economic structure, development, leading industries, culture, and region. Hence, we wanted to test differences among countries. Should one observe a significant difference among countries, it is essential to make some modifications to the model; otherwise, the results would be biased. Our data consist of companies from GCC countries. These countries have similarities in cultural issues, they are in the same region, their economic activities are depending on petroleum and gas, and life standards between these countries do not reflect an important difference. However, the magnitude of economies, population, and level of dependence on oil may differ. We used F-test to see the significance level of these differences. We took six models with no dummies (Models $1,2,3,16,17,18)$ and 6 models with country dummies (Models 4, 5, 6, 19, 20, 21). For cash flow approach, we wanted to see the difference between models 1, 2, 3 and Models with dummies $(4,5,6)$, then we did the same for balance sheet approach, which includes no dummy variables (Models 16, 17, 18) and country dummy variables (Models 19, 20, 21). We calculated an F statistic using $\mathrm{R}^{2}$ of models, and results are reported in Table 4.

The results for country control variables reveal distinct patterns for the balance sheet approach and cash flow approach. In the cash flow approach, adding Country dummy variables increases the power of the model significantly. On the other hand, models using the balance sheet approach have no significant difference in terms of country control variables. Partial coefficients reveal that UAE has a significantly lower number of accruals compared to other countries. Though some different countries may show significance in some models, it is difficult to derive an overall insight into other countries. 
In Hypothesis 4, we examined the significance of sector control variables. We developed two groups of industrial classification, the first group takes fields of operations as the main criterion, and it has three elements: production, retail-wholesale, and service. In the second category, we used the classification that is based upon the categories determined by the database. In this group, the elements are classified in a more detailed way, and it has nine subcategories: Basic materials, consumer cyclicals, consumer non-cyclicals, energy, healthcare, industrials, technology, telecommunication, and utilities. We tested the significance of additional control variables for both groups and for both cash flow and balance sheet approach models. The results are presented in Table 5 .

The results for industry control variables reveal that, for the cash flow approach, broad dummy categories (all are significant at $1 \%$ ) have more significance compared to narrow dummy categories (all are significant at 10\%). For models based on a balance sheet approach, both categories reach $1 \%$ significance.
In Hypothesis 5, we examined the significance of an aggregate model, including country and broad industry control variables. The model includes five countries and eight industry dummies along with the main variables of three accrual models (JM, MJM, PMM). Compared to the base models with no dummies, aggregate models exhibit at least two times more goodness of fit (R2) scores and considerably higher overall significances. Table 6 shows the F statistics report of the difference between base and aggregate models for CFS and BS approaches.

We also tested how significant aggregate models are compared to models with country dummies and models with broad industry dummies. In these tests, results reveal that, regarding cash flow models, aggregate models show a significant superiority in overall significance against both country and industry models. However, the models using the balance sheet approach reveal no significant difference between aggregate models and models with country control variables, whereas there is a significant difference between the aggregate model and broad industry control variable models.

Table 5: Narrow-Broad Industry Comparison (CFS \& BS Approaches)

\begin{tabular}{|c|c|c|}
\hline \multicolumn{3}{|c|}{ Models Using Cash Flow Approach } \\
\hline Base Model & Narrow Industry Dummy & F-Statistic \\
\hline Model 1 (JM) & Model 7 (JM) & $12.490^{*}$ \\
\hline Model 2 (MJM) & Model 8 (MJM) & $12.211^{*}$ \\
\hline Model 3 (PMM) & Model 9 (PMM) & $41.253^{* * *}$ \\
\hline \multicolumn{3}{|c|}{ Models Using the Cash Flow Approach } \\
\hline Base Model & Broad Industry Dummy & F-Statistic \\
\hline Model 1 (JM) & Model $10(\mathrm{JM})$ & $42.221^{* * *}$ \\
\hline Model 2 (MJM) & Model 11 (MJM) & $39.444^{* * *}$ \\
\hline Model 3 (PMM) & Model 12 (PMM) & $35.372^{* * *}$ \\
\hline \multicolumn{3}{|c|}{ Models Using the Balance Sheet Approach } \\
\hline Base Model & Narrow Industry Dummy & F-Statistic \\
\hline Model 16 (JM) & Model 22 (JM) & $36.326^{* * *}$ \\
\hline Model 17 (MJM) & Model 23 (MJM) & $32.969^{* * *}$ \\
\hline Model 18 (PMM) & Model 24 (PMM) & $36.314^{* * *}$ \\
\hline \multicolumn{3}{|c|}{ Models Using the Balance Sheet Approach } \\
\hline Base Model & Broad Industry Dummy & F-Statistic \\
\hline Model 16 (JM) & Model 25 (JM) & $37.050^{* * *}$ \\
\hline Model 17 (MJM) & Model 26 (MJM) & $34.636^{* * *}$ \\
\hline Model 18 (PMM) & Model 27 (PMM) & $34.147^{* * *}$ \\
\hline
\end{tabular}


Table 6: Comparison of the Aggregate Models

\begin{tabular}{|c|c|c|}
\hline \multicolumn{3}{|c|}{ Models Using the Cash Flow Approach } \\
\hline Base model & Aggregate Model & F-Statistic \\
\hline Model 1 (JM) & Model $13(\mathrm{JM})$ & $33.016^{* * *}$ \\
\hline Model 2 (MJM) & Model 14 (MJM) & $31.365^{\star * *}$ \\
\hline Model 3 (PMM) & Model 15 (PMM) & $26.402^{* * *}$ \\
\hline \multicolumn{3}{|c|}{ Models Using the Balance Sheet Approach } \\
\hline Base model & Aggregate Model & F-Statistic \\
\hline Model 16 (JM) & Model 28 (JM) & $23.543^{* * *}$ \\
\hline Model 17 (MJM) & Model 29 (MJM) & $22.153^{* * *}$ \\
\hline Model 18 (PMM) & Model 30 (PMM) & $21.662^{\star * *}$ \\
\hline
\end{tabular}

\section{Discussion and Conclusion}

In this study, we constructed thirty models, and half of these models use total accruals derived by the cash flow approach, and the other half uses the balance sheet approach. Though there is not a significant difference between the expected values and variances of them, the cash flow approach shows a more stable pattern, and it shows the better significance and $\mathrm{R}^{2}$ scores compared to the balance sheet approach. Another advantage of the cash flow approach is, it is easier to calculate and needs less variable for calculation, this makes sense in a way that, less amount of variables in the calculation of accruals also results in less missing observations in the dataset particularly when panel data is used for longer periods.

Secondly, we compared models used in the literature. We selected Jones Model, Modified Jones Model, and Performance Matched Model because these models are considered as the most widely used and most cited models in the literature. PMM exhibits the highest significance. It leads to the fact that some variables as an indicator or company's performance should be added to the model in order to reduce bias and generate more robust results. On the other hand, as Kothari states, it reduces heteroscedasticity in the models (Kothari et al., 2005). The comparison between JM and MJM, however, is surprising. The Jones model includes a change in revenues as an indicator of accruals, yet, Dechow et al. (1995) argue for adding the change in receivables to the model to get a better fit, and their model has become a milestone in the literature and used and cited afterward. On the contrary, our results show an inverse pattern between JM and MJM models. JM models have higher explanatory power and significance. This may occur due to the business practices of companies that are subject to study, and there may be more variance among receivables than revenues resulting in inconsistent and inefficient results with higher variances.
The rest of our models focus on the control variables for country-wise and industrial differences. Our results reveal the essence of adding country dummies for a higher power of the test even in such regions like GCC, where the countries with similarities in business practices as well as economic structure and culture come together. Furthermore, we tested for industrial dummies, and our findings suggest that a broader industrial classification based on business lines would provide more efficient results.

In the final count, we combined country control variables and industrial control variables, and these models provide the highest explanatory powers and significances. Our findings reveal the importance of classification among countries and industries as well as controlling them in models. Secondly, among accrual models, PMM of Kothari et al. (2005) should be used as it tells more on variability in regressand.

\section{References}

Al-Amri, K., Al Shidi, S., Al Busaidi, M., \& Akguc, S. (2017). Real earnings management in public vs. private firms in the GCC countries: a risk perspective. Journal of Applied Accounting Research, 34(1), 74-94.

Alareeni, B. (2018a). Does corporate governance influence earnings management in listed companies in Bahrain Bourse?. Journal of Asia Business Studies, 12(4), 551-570.

Alareeni, B. (2018b). The impact of firm-specific characteristics on earnings management: evidence from GCC countries. International Journal of Managerial and Financial Accounting, 10(2), 85-104.

Al-Thuneibat, A. A., Al-Angari, H. A., \& Al-Saad, S. A. (2016). The effect of corporate governance mechanisms on earnings management. Review of International Business and Strategy, 26(1), 2-32.

Amin, Z. Y., \& Amin, M. Y. (2015) Impact of Accounting Standards on Earnings Management in Selected Middle-East Countries, 
International Journal of Sciences: Basic and Applied Research, 20(2), 316-333.

Baatour, K., \& Othman, H. B. (2016). Legal origin, economic freedom and earnings management practices: MENA evidence. International Journal of Accounting, Auditing and Performance Evaluation, 12(1), 1-23.

Baatour, K., Othman, H. B., \& Hussainey, K. (2017). The effect of multiple directorships on real and accrual-based earnings management. Accounting Research Journal, 30(4), 395-412.

Beaver, W.H., \& McNichols, M.F. (1998). The Characteristics and Valuation of Loss Reserves of Property Casualty Insurers. Review of Accounting Studies, 3(1-2), 73-95

Beneish, M. D. (1997). Detecting Gaap Violation: Implications for Assessing Earnings Management among Firms with Extreme Financial Performance. Journal of Accounting and Public Policy, 16(3), 271-309.

Beneish, M.D.(1999). The Detection of Earnings Manipulation. Financial Analysts Journal, 55(5), 24-36.

Christodoulou, D., Ma, L., Vasnev, A. (2018). Inference-inresiduals as an Estimation Method for Earnings Management. Abacus, 54(2), 154-180.

Cohen, D. A., \& Zarowin, P. (2010). Accrual-based and real earnings management activities around seasoned equity offerings. Journal of Accounting and Economics, 50(1), 2-19.

Cohen, D. A., Dey, A., \& Lys, T. Z. (2008). Real and accrual-based earnings management in the pre-and post-Sarbanes-Oxley periods. The Accounting Review, 83(3), 757-787.

Dang, H. N., \& Tran, D. M., (2019). Relationship between Accrual Anomaly and Stock Return: The Case of Vietnam. Journal of Asian Finance, Economics and Business, 6(4), 19-26. https:// doi.org/10.13106/jafeb.2019.vol6.no4.19

Dang, H. N., Nguyen, T. T. C., \& Tran, D. M. (2020). The Impact of Earnings Quality on Firm Value: The Case of Vietnam. Journal of Asian Finance, Economics and Business, 7(3), 63-72. https:// doi.org/10.13106/jafeb.2020.vo17.no3.63

DeAngelo, L. E. (1986). Accounting Numbers as Market Valuation Substitutes: A Study of Management Buyouts of Public Stockholders. The Accounting Review, 61(3), 400-420.

Dechow, P. M., Sloan, R. G., \& Sweeney A.P. (1995). Detecting Earnings Management. The Accounting Review, 20(2), 193225.

Dechow, P. M. \& Skinner, D. G. (2000). Earnings Management: Reconciling the Views of Accounting Academics, Practitioners, and Regulators. Accounting Horizons, 14(2), 235-250.

Doukakis, L. C. (2014). The effect of mandatory IFRS adoption on real and accrual-based earnings management activities. Journal of Accounting and Public Policy, 33(6), 551-572.

Farooq, O., \& AbdelBari, A. (2015). Earnings management behaviour of Shariah-compliant firms and non-Shariahcompliant firms. Journal of Islamic Accounting and Business Research, 6(2), 173-188.

Francis, J., Olsson, P., \& Schipper, K. (2008). Earnings quality. Norwell, MA: Now Publishers Inc.
Gerged, A. M., Al-Haddad, L. M., \& Al-Hajri, M. O. (2020). Is earnings management associated with corporate environmental disclosure? Accounting Research Journal, 33(1), 167-185.

Giedt, J. (2018). Modelling Receivables and Deferred Revenues to Detect Revenue Management. Abacus, 54(2), 181-209

Habbash, M., \& Alghamdi, S. (2017). Audit quality and earnings management in less developed economies: the case of Saudi Arabia. Journal of Management \& Governance, 21(2), 351-373.

Healy, P. M. (1985). The Effect of Bonus Schemes on Accounting Decisions. Journal of Accounting and Economics, 7(1-3), 85-107.

Hribar, P., \& Collins, D. W. (2002). Errors in estimating accruals: Implications for empirical research. Journal of Accounting Research, 40(1), 105-134.

Jackson, A. (2018). Discretionary Accruals: Earnings Management ... or Not? Abacus, 54(2), 136-153

Jones, J. J. (1991). Earnings Management During Import Relief Investigations. Journal of Accounting Research, 29(2), 193228.

Juhmani, O. I. (2017). The impact of audit committee characteristics on earnings management in the pre-and post-Bahraini corporate governance code 2011. Asian Journal of Economics, Business and Accounting, 4(3), 1-12.

Kothari, S. P., Leone A. J., \& Wasley C. E. (2005). Performance Matched Discretionary Accrual Measures. Journal of Accounting \& Economics, 39(1), 163-197.

Kuo, J. M., Ning, L., \& Song, X. (2014). The real and accrualbased earnings management behaviors: Evidence from the split share structure reform in China. The International Journal of Accounting, 49(1), 101-136.

McNichols, M. F., \& Wilson, G. F. (1988). Evidence of Earnings Management from the Provision for Bad Debts. Journal of Accounting Research, 26 (Supplement), 1-31.

Mulford, C. W. \& Comiskey, E. (2002), The Financial Numbers Game Detecting Creative Accounting Practices. Hoboken, NJ: John Wiley \& Sons, Inc.

Nguyen, A. H. \& Duong, C. T., (2019) Provincial Governance Quality and Earnings Management: Empirical Evidence from Vietnam. Journal of Asian Finance, Economics and Business, 7(2), 43-52. https://doi.org/10.13106/jafeb.2020.vol7.no2.43

Roychowdhury, S. (2006). Earnings management through real activities manipulation. Journal of Accounting and Economics, 42(3), 335-370.

Schipper, K. (1989). Commentary on Earnings Management. Accounting Horizons, 3(4), 91-103.

Wahlen, J. (1994). The Nature of Information in Commercial Bank Loan Loss Disclosures. The Accounting Review, 69(3), 455478.

Zang, A. Y. (2012). Evidence on the trade-off between real activities manipulation and accrual-based earnings management. The Accounting Review, 87(2), 675-703. 